\title{
Beet Armyworm, Spodoptera exigua (Hübner) (Insecta: Lepidoptera: Noctuidae) ${ }^{1}$
}

\section{J. L. Capinera ${ }^{2}$}

\section{Introduction and Distribution}

The beet armyworm originated in Southeast Asia. It was first discovered in North America about 1876, when it was found in Oregon, and it reached Florida in 1924. It rarely overwinters in areas where frost kills its host plants. Thus, overwintering is generally limited to Arizona, Florida, and Texas. Nevertheless, beet armyworm invades the southern half of the United States (Maryland to Colorado to northern California, and south) annually. Except in greenhouses, it rarely is a pest except in southern states.

\section{Life Cycle and Description}

Seasonal activity varies considerably according to climate. In warm locations such as Florida, all stages can be found throughout the year, although development rate and overall abundance are reduced during the winter months (Tingle and Mitchell 1977). The life cycle can be completed in as few as 24 days, and six generations have been reared during five months of summer weather in Florida (Wilson 1934).
Egg

Eggs are laid in clusters of 50 to 150 eggs per mass. Normal egg production is about 300 to 600 per female. Eggs are usually deposited on the lower surface of the leaf, and often near blossoms and the tip of the branch. The individual eggs are circular when viewed from above, but when examined from the side the egg is slightly peaked, tapering to a point. The eggs are greenish to white in color, and covered with a layer of whitish scales that gives the egg mass a fuzzy or cottony appearance. Eggs hatch in two to three days during warm weather.

\section{Larva}

There normally are five instars, although additional instars are sometimes reported. Duration of the instars under warm (summer) conditions is reported to be $2.3,2.2,1.8,1.0$, and 3.1 days, respectively (Wilson 1932), and at constant 30 degrees $\mathrm{C}$ instar development time was reported by Fye and McAda (1972) to be 2.5, 1.5, 1.2, 1.5, and 3.0 days, respectively. Head capsule widths average $0.25,0.45,0.70,1.12$, and $1.80 \mathrm{~mm}$, respectively.

1. This document is EENY-105, one of a series of Featured Creatures from the Entomology and Nematology Department, Florida Cooperative Extension Service, Institute of Food and Agricultural Sciences, University of Florida. Published: July 1999. This document is also available on Featured Creatures Website at http://creatures.ifas.ufl.edu. Please visit the EDIS Website at http://edis.ifas.ufl.edu. Additional information on these organisms, including many color photographs, is available at the Entomology and Nematology Department website at http://entnemdept.ifas.ufl.edu/.

2. J. L. Capinera, professor/chairman, Enomology and Nematology Department, Cooperative Extension Service, Institute of Food and Agricultural Sciences, University of Florida, Gainesville, 32611.

The Institute of Food and Agricultural Sciences is an equal opportunity/affirmative action employer authorized to provide research, educational information and other services only to individuals and institutions that function without regard to race, color, sex, age, handicap, or national origin. For information on obtaining other extension publications, contact your county Cooperative Extension Service office. Florida Cooperative Extension Service/Institute of Food and Agricultural Sciences/University of Florida/Christine Taylor Waddill, Dean. 


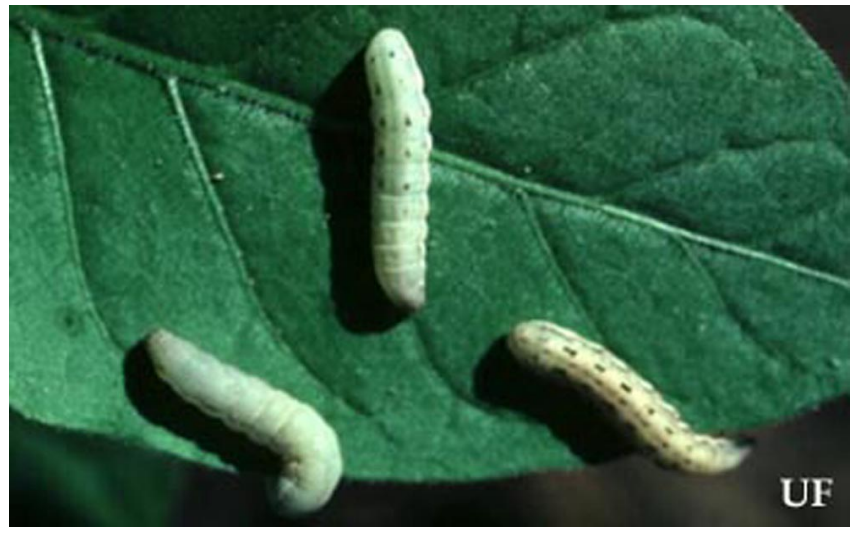

Figure 1. Partly grown larvae of the beet armyworm, Spodoptera exigua (Huebner), showing variation in color pattern. Credits: J.L. Capinera, University of Florida

The larvae are pale green or yellow in color during instars 1-2, but acquire pale stripes during instar 3. During instar 4 larvae, are darker dorsally, and possess a dark lateral stripe. Larvae during instar 5 are quite variable in appearance, tending to be green dorsally with pink or yellow color ventrally and a white stripe laterally. A series of dark spots or dashes is often present dorsally and dorsolaterally. Sometimes larvae are very dark in color. The spiracles are white with a narrow black border. The body is practically devoid of hairs and spines. In the southern states, the larva of beet armyworm is easily confused with southern armyworm, Spodoptera eridania (Cramer), but southern armyworm can be distinguished by the presence of a large dark spot laterally on the first abdominal segment that disrupts the lateral stripe. Beet armyworm occasionally bears a spot laterally, but if present it occurs on the mesothorax, not on the first abdominal segment.

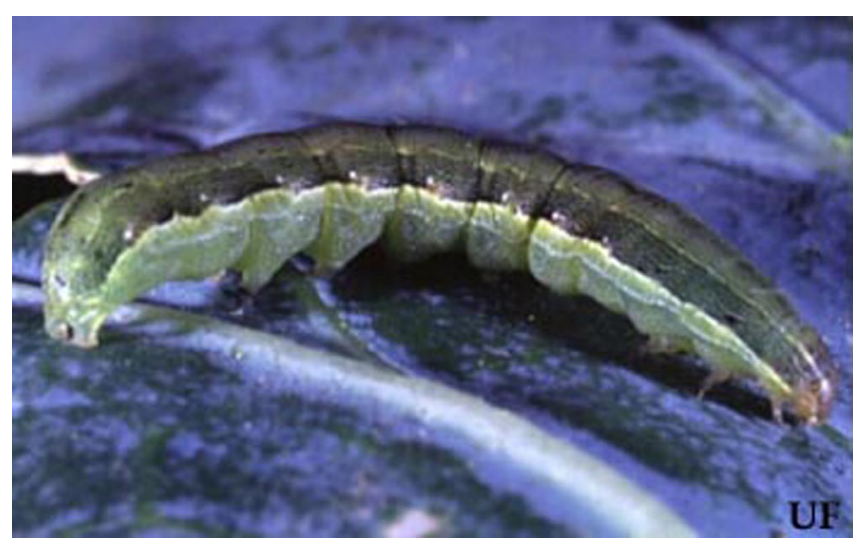

Figure 2. Typical mature larva of beet armyworm, Spodoptera exigua (Huebner). Credits: J.L. Capinera, University of Florida

\section{Pupa}

Pupation occurs in the soil. The chamber is constructed from sand and soil particles held together with an oral secretion that hardens when it dries. The pupa is light brown in color and measures about 15 to $20 \mathrm{~mm}$ in length. Duration of the pupal stage is six to seven days during warm weather.

\section{Adult}

The moths are moderately sized, the wing span measuring 25 to $30 \mathrm{~mm}$. The forewings are mottled gray and brown, and normally with an irregular banding pattern and a light colored bean-shaped spot. The hind wings are a more uniform gray or white color, and trimmed with a dark line at the margin. Mating occurs soon after emergence of the moths, and oviposition begins within two to three days. Oviposition extends over a three to seven day period, and the moths usually perish within nine to 10 days of emergence. Heppner (1998) provides a key to the adults of North American Spodoptera.

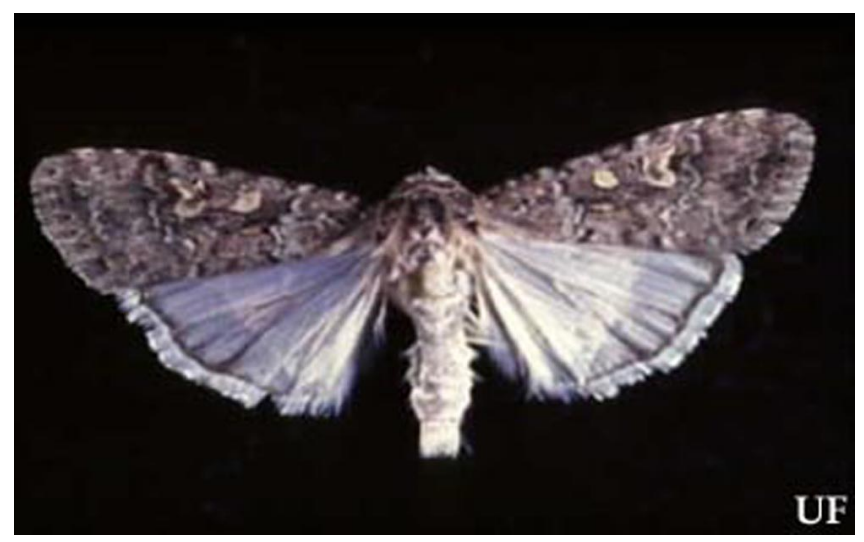

Figure 3. Adult beet armyworm, Spodoptera exigua (Huebner). Credits: J.L. Capinera, University of Florida

\section{Host Plants}

The beet armyworm has a wide host range, occurring as a serious pest of vegetable, field, and flower crops. Among susceptible vegetable crops are asparagus, bean, beet, broccoli, cabbage, cauliflower, celery, chickpea, corn, cowpea, eggplant, lettuce, onion, pea, pepper, potato, radish, spinach, sweet potato, tomato, and turnip. Field crops damaged include alfalfa, corn, cotton, peanut, safflower, sorghum, soybean, sugarbeet, and tobacco. Weeds also are suitable for larval development, including 
such common plants as lambsquarters, Chenopodium album; mullein, Verbascum sp.; pigweed, Amaranthus spp.; purslane, Portulaca spp.; Russian thistle, Salsola kali; parthenium, Parthenium sp.; and tidestromia,

Tidestromia sp.

\section{Damage}

Larvae feed on both foliage and fruit. In Florida it is regarded as a serious defoliator of flower crops and cotton, though much of the injury is induced by insecticide use that interferes with natural enemy activity. Young larvae feed gregariously and skeletonize foliage. As they mature, larvae become solitary and eat large irregular holes in foliage. They also burrow into the crown or center of the head on lettuce, or on the buds of cole crops. As a leaf feeder, beet armyworm consumes much more cabbage tissue than the diamondback moth, Plutella xylostella (Linnaeus), but is less damaging than the cabbage looper, Trichoplusia ni (Huebner) (East et al. 1989).

Tomato fruit is most susceptible to injury, especially near fruit maturity, but beet armyworm is not considered to be as threatening to tomato as is the corn earworm, Helicoverpa zea (Boddie) (Zalom et al. 1986).

\section{Sampling}

Pheromone traps can be used to detect the presence of adult beet armyworm. Visual sampling for damage and larvae, combined with an action threshold of 0.3 larvae per plant, was used successfully on cabbage in south Texas to determine the need for crop treatment with insecticides (Cartwright et al. 1987). Regular monitoring of crops, probably about twice per week, is recommended because adults frequently invade from surrounding crops or weeds.

\section{Natural Enemies}

Numerous native natural enemies have adapted to this pest. Among the most common parasitoids are Chelonus insularis Cresson, Cotesia marginiventris (Cresson), and Meteorus autographae (Muesbeck) (all Hymenoptera: Braconidae), and the tachinid Lespsia archippivora (Riley) (Diptera: Tachinidae) (Oatman and Platner 1972, Ruberson et al. 1994).
Predators frequently attack the eggs and small larvae; among the most important are minute pirate bugs, Orius spp. (Hemiptera: Anthocoridae); bigeye bugs, Geocoris spp. (Hemiptera: Lygaeidae); damsel bugs, Nabis spp. (Hemiptera: Nabidae); and a predatory shield bug, Podisus maculiventris (Say). Pupae are subject to attack, especially by the red imported fire ant, Solenopsis invicta Buren. Fungal diseases, Erynia sp. and Nomurea rileyi, and a nuclear polyhedrosis virus also inflict some mortality (Wilson 1933 \&1934, Ruberson et al. 1994). The important mortality factors vary among crops, and among geographic regions. None except the nuclear polyhedrosis virus are highly specific to beet armyworm, which may explain why they are not especially effective. Virus is considered to be the most important mortality factor.

\section{Insecticides}

In the Southeast and Southwest, the relatively high abundance of beet armyworm has stimulated frequent application of insecticides to foliage. Insecticide resistance is a major problem in management of this insect, possibly because it attacks crops such as flowers, cotton, and vegetables crops that are treated frequently with insecticides. Beet armyworm abundance is favored by frequent insecticide use, and it is considered to be a secondary or induced pest in some crops (Eveleens et al. 1973). Also, intensive use of insecticides for beet armyworm control in vegetables such as celery has stimulated outbreaks of other pests, principally American serpentine leafminer, Liriomyza trifolii (Burgess).

Beet armyworm larvae are susceptible to neem products (Prabhaker et al. 1986). Eggs can be killed with petroleum oil, and both eggs and young larvae can be controlled with foliar applications of $5 \%$ cottonseed oil, but this concentration is damaging to some plants (Butler and Henneberry 1990).

Pheromones can also be used disrupt mating and inhibit or eliminate reproduction. Saturation of the atmosphere around beet armyworm-susceptible crops has been estimated to reduce mating by $97 \%$

(Wakamura and Takai 1992).

Insect Management Guide for Field Crops 
Insect Management Guide for Vegetables

Insect Management Guide for Ornamentals

\section{Biological Control}

Several insect pathogens may prove to be useful for suppression of beet armyworm. A nuclear polyhedrosis virus isolated from beet armyworm is fairly effective as a bioinsecticide under greenhouse conditions, where inactivation by ultraviolet light in sunlight is not a severe problem. The fungus Beauveria bassiana has the same attributes and limitations. Entomopathogenic nematodes (Rhabditida: Steinernematidae and Heterorhabditidae) successfully infect both larvae and adults of beet armyworm.

\section{Selected References}

Butler, Jr., G.D., and T.J. Henneberry. 1990. Cottonseed oil and Safer insecticidal soap: effects on cotton and vegetable pests and phytotoxicity. Southwestern Entomol. 15:257-264.

Capinera, J.L. 2001. Handbook of Vegetable Pests. Academic Press, San Diego. 729pp

Cartwright, B., J.V. Edelson, and C. Chambers. 1987. Composite action thresholds for the control of lepidopterous pests on fresh-market cabbage in the lower Rio Grande Valley of Texas. J. Econ. Entomol. 80:175-181.

East, D.A., J.V. Edelson, and B. Cartwright. 1989. Relative cabbage consumption by the cabbage looper (Lepidoptera: Noctuidae), beet armyworm (Lepidoptera: Noctuidae), and diamondback moth (Lepidoptera: Plutellidae). J. Econ. Entomol. 82:1367-1369.

Eveleens, K.G., R. van den Bosch, and L.E. Ehler. 1973. Secondary outbreak induction of beet armyworm by experimental insecticide applications in cotton in California. Environ. Entomol. 2:497-503.

Fye, R.E. and W.C. McAda. 1972. Laboratory studies on the development, longevity, and fecundity of six lepidopterous pests of cotton in Arizona.

USDA Tech. Bull. 1454. 73 pp.
Heppner, J.B. 1998. Spodoptera armyworms in Florida (Lepidoptera: Noctuidae). Florida Dept. Agric. \& Cons. Serv., Div. Plant Ind. Entomol. Cir. $390.5 \mathrm{p}$.

Oatman, E.R. and G.R. Platner. 1972. An ecological study of lepidopterous pests affecting lettuce in coastal southern California. Environ. Entomol. 1:202-204.

Prabhaker, N., D.L. Coudriet, A.N. Kishaba, and D.E. Meyerdirk. 1986. Laboratory evaluation of neem-seed extract against larvae of the cabbage looper and beet armyworm (Lepidoptera: Noctuidae). J. Econ. Entomol. 79:39-41.

Ruberson, J.R., G.A. Herzog, W.R. Lambert, and W.J. Lewis. 1994. Management of the beet armyworm (Lepidoptera: Noctuidae) in cotton: role of natural enemies. Florida Entomol. 77:440-453.

Tingle, F.C. and E.R. Mitchell. 1977. Seasonal populations of armyworms and loopers at Hastings, Florida. Florida Entomol. 60:115-122.

Wakamura, S. and M. Takai. 1992. Control of the bet armyworm in open fields with sex pheromone. Pages 115-125 in N.S Talekar (ed.) Diamondback Moth and other Crucifer Pests. Asian Research and Development Center, Taipei, Taiwan.

Wilson, J.W. 1932. Notes on the biology of Laphygma exigua Huebner. Florida Entomol. 16:33-39.

Wilson, J.W. 1933. The biology of parasites and predators of Laphygma exigua Huebner reared during the season of 1932. Florida Entomol. 17:1-15.

Wilson, J.W. 1934. The asparagus caterpillar: its life history and control. Florida Agric. Exp. Stn. Bull. 271:1-26.

Zalom, F.G., L.T. Wilson, and M.P. Hoffmann. 1986. Impact of feeding by tomato fruitworm, Heliothis zea (Boddie) (Lepidoptera: Noctuidae), and beet armyworm, Spodoptera exigua (Huebner) (Lepidoptera: Noctuidae), on processing tomato fruit quality. J. Econ. Entomol. 79:822-826. 